\title{
HUBUNGAN STATUS GIZI DAN PENDAPATAN TERHADAP KEJADIAN TUBERKULOSIS PARU
}

\author{
Isma Yuniar ${ }^{1}$, Sarwono1, Susi Dwi Lestari ${ }^{1}$ \\ ${ }^{1}$ STIKES Muhammadiyah Gombong
}

\begin{abstract}
Diperkirakan sekitar 2,7 juta jiwa meninggal karena tuberkolusis paru. Setiap tahunnya di seluruh dunia masalah kesehatan dimana Indonesia cukup memberikan kontribusi ke tingkat dunia. Dibuktikan dengan saat ini berada pada peringkat empat dengan beban tuberkolusis tertinggi dunia, yaitu setelah China, India, dan Afrika Selatan.Status gizi adalah salah satu faktor terpenting dalam pertahanan tubuh terhadap infeksi tuberkolusis. Pada keadaan gizi yang buruk, maka reaksi kekebalan tubuh akan melemah sehingga kemampuan dalam mempertahankan diri terhadap infeksi menjadi menurun. Faktor lain yang mempengaruhi statu sgizi seseorang adalah status sosial ekonomi. Pendapatan per kapita pasien Tuberkulosis Paru menjadi salah satu faktor yang berhubungan dengan status gizi pada pasien Tuberkulosis Paru. Tujuan penelitian adalah untuk mengetahui hubungan antara pendapatan, status nutrisi terhadap kejadian tuberkolusis paru. Penelitian ini merupakan penelitian kuantitatif yang menggunakan metode survei analitik dengan pendekatan case control. Hasil penelitian menunjukkan hubungan yang bermakna antara status gizi dengan kejadian Tuberkulosis paru dengan nilai $\mathrm{OR}=3,484(\mathrm{CI}=1,246-9$, 747) yang berarti status gizi kurang beresiko menderita Tuberkulosis paru sebesar 3,4 kali dibandingkan dengan status gizi cukup. Terdapat hubungan yang bermakna antara pendapatan dengan kejadian Tuberkulosis paru dengan nilai $\mathrm{OR}=4,421(\mathrm{CI}=1,638-11,930)$ yang berarti responden dengan pendapatan rendah beresiko menderita Tuberkulosis paru sebesar 4,4 kali dibandingkan dengan responden yang pendapatannya tinggi.
\end{abstract}

Kata kunci: Status gizi, pendapatan, kejadian TB

\begin{abstract}
The relationship between income, nutritional status on the incidence of pulmonary tuberculosis.It is estimated that around 2.7 million people die from pulmonary tuberculosis every year throughout the world. is a health problem where Indonesia contributes enough to the world level. It is proven that currently it is ranked fourth with the world's highest tuberculosis burden, namely after China, India and South Africa. Nutritional status is one of the most important factors in the body's defense against tuberculus infections. In poor nutrition, the immune reaction will weaken so that the ability to defend against infection decreases. Other factors that affect a person's nutritional status are socioeconomic status. Per capita income of patients with pulmonary tuberculosis is one of the factors related to nutritional status in patients with pulmonary tuberculosis. The purpose of the study was to determine the relationship between income, nutritional status on the incidence of pulmonary tuberculosis. This research is a quantitative study that uses analytical survey methods with a case control approach. The results showed a significant relationship between nutritional status with the incidence of pulmonary tuberculosis with an $O R=3.484(C I=1.246-9,747)$ which means less nutritional status at risk of suffering from pulmonary tuberculosis by 3.4 times compared to adequate nutritional status. There is a significant relationship between income with the incidence of pulmonary tuberculosis with $\mathrm{OR}=4.421(\mathrm{CI}=1.638$ 11,930) which means that respondents with low income are at risk of suffering from pulmonary tuberculosis by 4.4 times compared to respondents with high income.
\end{abstract}

Keywords: Nutritional status, income, incidence of TB 


\section{Pendahuluan}

Tuberkulosis paru merupakan penyebab kematian utama di banyak negara-negara berkembang.Data WHO mencatat Indonesia menempati urutan ke-3 sedunia dalam hal jumlah penderita Tuberculosis paru, setelah India dan China(WHO, 2013). Insidendan kematian akibat tuberkulosis telah menurun karena berbagai upaya pengendalian yangtelah dilakukan namun diperkirakan kematian akibat tuberkulosis pada tahun 2014 adalah 1,2 juta orang dari 9,6 juta orang penderita tuberkulosis paru. Penderita tuberkulosis paru terbanyak yaitu berturut-turut $23 \%$, $10 \%$ dan $10 \%$ adalah India, Indonesia dan China dari seluruh penderita didunia. (WHO, 2015).

Pada tahun 2015 ditemukan jumlah kasus tuberkulosis sebanyak 330.910kasus, mengalami kenaikan dibandingkan dengan jumlah kasus tuberkulosis yang ditemukan pada tahun 2014 yaitu sebesar 324.539 kasus. Kasus tuberkulosis tertinggi ditemukan di tiga provinsi yang mempunyai jumlah penduduk yang besar yaitu Jawa Barat, Jawa Timur dan Jawa Tengah, yaitu terdapat kasus tuberkulosis sebesar 38\% dari jumlah seluruh kasus baru di Indonesia.

Berdasarkan data Dinas Kesehatan Provinsi Kebumen pada tahun 2015 ditemukan jumlah kasus Tuberkulosis paru baru BTA positifsebanyak 672 kasus. Hal ini mengalami kenaikan dibandingkan jumlah kasus Tuberkulosis paru baru BTA positif pada tahun 2014 yaitu sebanyak 435 kasus. Di tahun 2015 ini pencapaian CNR wilayah Kabupaten Kebumen adalah 56,90 per 100.000 penduduk. Pada tahun 2011 2014 CNR kasus Tuberkulosis paru di Kebumen mengalami penurunan dan naik pada tahun 2015. Angka CNR kasus baru BTA positiftahun 2015 naik jika dibandingkan dengan pencapaian tahun 2014 yaitu 36,97 per 100.000 penduduk.

Jumlah penduduk miskin dan hampir miskin yang terdapat di Kabupaten Kebumen pada tiga tahun terakhir mengalami peningkatan,tahun 2011 jumlahnya adalah sebesar 535,252. Berdasarkan hasil penelitian Sari dkk (2012) menunjukkan bahwa Seseorang dengan tingkat sosial ekonomi yang baik akan memiliki tingkat kesehatan yang baik pula.Tingkat sosial ekonomi yang rendah mengakibatkan rendahnya pengetahuan mengenai penyakit Tuberkulosis Paru BTA positif serta sulitnya mendapatkan akses pelayanan kesehatan yang baik, sehingga perbaikan kondisi sosial ekonomi masyarakat diperlukan untuk mencegah timbulnya penyakit menular seperti Tuberkulosis Paru BTA positif.

Menurut Binongko (2012) dalam Maksalmina (2013), salah satu faktor yang mempengaruhi penyakit Tuberkulosis adalah status gizi. Status gizi adalah salah satu faktor terpenting dalam pertahanan tubuh terhadap infeksi. Pada keadaan gizi yang buruk, maka reaksi kekebalan tubuh akan melemah sehingga kemampuan dalam mempertahankan diri terhadap infeksi menjadi menurun. faktor lain yang mempengaruhi status gizi seseorang adalah status sosial ekonomi. Pendapatan per kapita pasien Tuberkulosis Paru menjadi salah satu faktor yang berhubungan dengan status gizi pada pasien Tuberkulosis Paru (Patiung, 2014). Pendapatan keluarga dipengaruhi oleh jenis pekerjaan seseorang yang akan mempunyai dampak terhadap pola hidup sehari-hari diantaranya konsumsi makanan, pemeliharaan kesehatan selain itu juga akan mempengaruhi terhadap kepemilikan rumah (kontruksi rumah) (Rohman, 2012). Berdasarkan hasil penelitian Kartikasari (2011), menyatakan bahwa ada hubungan yang signifikan antara pekerjaan dengan status gizi.

Berdasarkan studi pendahuluan yang dilakukan pada tanggal 29 Oktober 2016 1 November 2016 di wilayah kerja Puskesmas Sempor 1 ditemukan data penderita Tuberkulosis Paru tahun 2015 adalah sebanyak 19 orang yang terdiri dari 11 laki-laki dan 8 perempuan sedangkan data penderita Tuberkulosis Paru pada tahun 2016 adalah sebanyak 23 orang yang 
terdiri dari 17 laki-laki dan 6perempuan namun 2 orang telah meninggal sehingga keseluruhan penderita Tuberkulosis paru tahun 2015-2016 adalah 40 orang.

Hasil data yang didapatkan dari 10 orang penderita Tuberkulosis paru adalah 8 orang memiliki pengetahuan yang kurang meskipun dari pihak Puskesmas Sempor 1 (petugas program Tuberkulosis paru) sudah memberikan penyuluhan terkait penyakit Tuberkulosis paru namun hanya 2 orang yang memiliki pengetahuan yang cukup. Delapan orang dengan pendapatan rendah dikarenakan mayoritas pekerjaan dari masyarakat di wilayah kerja Puskesmas Sempor 1 adalah buruh, baik buruh tani ataupun bangunan dan ada pula penderita Tuberkulosis paru yang tidak bekerja karena penyakitnya tersebut. Delapan orang dengan gizi yang kurang akibat pendapatan yang rendah menyebabkan ketidak mampuan menyediakan makanan yang bergizi dan pengetahuan yang kurang menyebabkan seseorang kesulitan untuk menerima konsep hidup sehat secara mandiri, kreatif dan berkesinambungan. Berdasarkan fenomena tersebut peneliti tertarik untuk melakukan penelitian tentang "Faktorfaktor yang beresiko terhadap kejadian Tuberkulosis Paru di wilayah kerja Puskesmas Sempor 1, Kabupaten Kebumen".

\section{Metode}

Penelitian ini merupakan penelitian kuantitatif yang menggunakan metode survei analitik dengan pendekatan case control. Populasi kasus dalam penelitian ini adalah semua penderita Tuberkulosis paru BTA positif di wilayah kerja Puskesmas Sempor 1, pada tahun 2015 2016sebanyak 40 orang.Populasi kontrol dalam penelitian ini adalah semua orang yang bukan penderita Tuberkulosis paru BTA positif atau belum dinyatakan menderita penyakit Tuberkulosis paru di wilayah kerja Puskesmas Sempor 1.Teknik pengambilan sampel dalam penelitian ini adalah dengan teknik total sampling sejumlah 40 responden. Teknik total sampling digunakan karena jumlah responden kasus adalah 40 responden. Pengambilan sampel kasus dan kontrol dilakukan di wilayah kerja Puskesmas Sempor1, Kabupaten Kebumen dengan perbandingan sampel kasus dan kontrol 1:1.Teknik analisa data menggunakan analisis univariat untuk menjelaskan atau mendeskripsikan karakteristik setiap variabel penelitian seperti pendapatan, dan status gizi yang disajikan dalam bentuk tabel, grafik atau presentase untuk memberi gambaran umum hasil penelitian. Analisa bivariate chi square dan perhitungan Odds Ratio (OR)

\section{Hasil Dan Pembahasan Tingkat Pendapatan}

Berdasarkan hasil penelitian di wilayah kerja Puskesmas Sempor 1 Kabupaten Kebumen di dapatkan hasil bahwa mayoritas responden mempunyai pendapatan rendah yaitu sebesar 51 $(63,75 \%)$ dari 80 responden yang terdiri dari 32 responden kasus (penderita Tuberkulosis paru) dan 19 responden kontrol (bukan penderita Tuberkulosis paru).

Pendapatan adalah hasil dari pekerjaan, pendapatan juga akan mempengaruhi gaya hidup seseorang. Pendapatan erat kaitannya dengan kemiskinan, masyarakat yang mempunyai pendapatan rendah biasanya mempunyai tingkat ekonomi yang rendah pula. Pendapatan yang rendah akan mempengaruhi seseorang dalam menjaga kesehatannya, karena pendapatan yang rendah berpengaruh pada pendidikan, pengetahuan, asupan makanan, pengobatan dan kondisi tempat tinggal. Hal ini sejalan dengan pendapat dari Haryanto (2011) dalam bukunya yang berjudul Sosiologi Ekonomi yang menyatakan bahwa ekonomi mempunyai kaitan erat dengan kejadian Tuberkulosis paru, telah diketahui bahwa pada umumnya angka kejadian Tuberkulosis paru meningkat pada status sosial ekonomi rendah (Noer, 2008). 
Seseorang yang mempunyai pendapatan lebih tinggi akan lebih mampu untuk menjaga kebersihan lingkungan rumah tangganya, menyediakan air minum yang baik, membeli makanan yang jumlah dan kualitasnya memadai serta mampu membiyai pemeliharaan kesehatan yang diperlukan (Helper, 2010)

$$
\text { Ristyo Sari P, dkk (2012) }
$$
menyatakan tingkat social ekonomi yang rendah mengakibatkan rendahnya pengetahuan mengenai penyakit Tuberkulosis paru serta sulitnya mendapat akses pelayanan kesehatan yang baik.

\section{Tingkat Status Nutrisi}

Berdasarkan hasil penelitian di wilayah kerja Puskesmas Sempor 1 Kabupaten Kebumen di dapatkan hasil bahwa mayoritas responden mempunyai status gizi kurang yaitu sebesar 56 (70\%) dari 80 responden yang terdiri dari 33 responden kasus (penderita Tuberkulosis paru) dan 23 responden kontrol (bukan penderita Tuberkulosis paru). Status gizi yang kurang akan membuat lemahnya daya imun (sistem kekebalan tubuh) dalam mempertahankan diri dari suatu penyakit. Kondisi kurangnya status gizi mayoritas responden terutama pada responden kasus (penderita Tuberkulosis paru) pada dasarnya disebabkan oleh banyak faktor. Dua faktordiantaranya adalah kurangnya pengetahuan tentang kebutuhan asupan makanan yang baik dan bergizi dan pendapatan (ekonomi) yang baik untuk memenuhi kebutuhan makanan bergizi. Jika tingkat pengetahuan gizi seseorang baik maka diharapkan asupan makanan baik sehingga status gizinya juga menjadi baik (Kartikasari, 2011). Meskipun begitu hal yang banyak mempengaruhi status gizi seseorang ditentukan oleh perilaku hidup sehat seseorang.

Menurut Binongko (2012) dalam Maksalmina (2013), salah satu faktor yang mempengaruhi penyakit Tuberkulosis adalah status gizi. Status gizi adalah salah satu faktor terpenting dalam pertahanan tubuh terhadap infeksi. Pada keadaan gizi yang buruk, maka reaksi kekebalan tubuh akan melemah sehingga kemampuan dalam mempertahankan diri terhadap infeksi menjadi menurun. Faktor lain yang mempengaruhi status gizi seseorang adalah status sosial ekonomi. Pendapatan per kapita pasien Tuberkulosis Paru menjadi salah satu faktor yang berhubungan dengan status gizi pada pasien Tuberkulosis Paru (Patiung, 2014).

Hal ini sejalan dengan yang dikemukakan Jefille dalam penelitian Sri Endah P (2012) bahwa faktor yang mempengaruhi status gizi adalah keadaan infeksi, konsumsi makanan, pengaruh budaya, sosial ekonomi dan produksi pangan. Status gizi merupakan variabel yang sangat berperan dalam timbulnya kejadian Tuberkulosis paru, tentu saja hal ini masih tergantung pada penyebab lain yang lebih utama yaitu bakteri mycobacterium tuberculosis. Seperti yang diketahui bakteri mycobacterium tuberculosis merupakan kuman yang suka tidur hingga bertahun - tahun dan apabila memiliki kesempatan untuk bangun dan menimbulkan penyakit maka timbulah kejadian penyakit Tuberkulosis paru (Ruswanto, 2010). Hal ini sesuai dengan pendapat Minardiarly dan Toyalis, bahwa faktor kurang gizi akan meningkatkan angka kesakitan atau kejadian Tuberkulosis paru.

\section{Hubungan pendapatan dengan kejadian Tuberkulosis paru di wilayah kerja Puskesmas Sempor 1, Kabupaten Kebumen}

Hasil penelitian yang dilakukan pada 80 responden diketahui bahwa terdapat51 $(63,75 \%)$ responden dengan pendapatan rendah dan $29(36,25 \%)$ responden dengan pendapatan tinggi. Hal ini menunjukkan bahwa mayoritas responden berpendapatan rendah. Hasil uji statistik didapatkan nilai $\mathrm{p}=0,005$ yang berarti $\mathrm{p}<$ alpha $(0,05)$, sehingga dengan alpha 5\% dapat disimpulkan bahwa terdapat hubungan yang bermakna antara pendapatan dengan kejadian Tuberkulosis paru. Hasil 
penelitian didapatkan nilai $\mathrm{OR}=4,421$ $(\mathrm{CI}=1,638-11$, 930) yang berarti responden dengan pendapatan rendah beresiko menderita Tuberkulosis paru sebesar 4,4 kali dibandingkan dengan responden yang pendapatannya tinggi.

Hasil penelitian ini sesuai dengan penelitian Ristyo Sari P, dkk (2012) yang menyatakan bahwa terdapat hubungan antara penghasilan dengan kejadian Tuberkulosis paru. Hasil penelitian ini menunjukkan bahwa Seseorang dengan tingkat sosial ekonomi yang baik akan memiliki tingkat kesehatan yang baik pula.Tingkat sosial ekonomi yang rendah mengakibatkan rendahnya pengetahuan mengenai penyakit Tuberkulosis Paru BTA positif serta sulitnya mendapatkan akses pelayanan kesehatan yang baik.

Dalam teori yang dikembangkan oleh Tjiptoherijanto dalam ekonomi pemenuhan kebutuhan, dengan pendapatan rendah kebutuhan akan sulit didapatkan sehingga berbagai masalah kesehatan mudah muncul seperti penyakit infeksi Tuberkulosis paru. Hasil penelitian ini sesuai dengan penelitian Fariz Muaz (2014) yang menyatakan bahwa penghasilan adalah faktor yang beresiko terhadap kejadian Tuberkulosis paru BTA positif.

Hubungan status gizi dengan kejadian Tuberkulosis paru di wilayah kerja Puskesmas Sempor 1, Kabupaten Kebumen

Hasil penelitian yang dilakukan pada 80 responden diketahui bahwa terdapat 56 (70\%) responden dengan status gizi kurang dan $24(30 \%)$ responden dengan status gizi cukup. Hal ini menunjukkan bahwa mayoritas responden mempunyai status gizi kurang. Hasil uji statistik didapatkan nilai $\mathrm{p}=0,028$ yang berarti $\mathrm{p}<$ alpha $(0,05)$, sehingga dengan alpha $5 \%$ dapat disimpulkan bahwa terdapat hubungan yang bermakna antara status gizi dengan kejadian Tuberkulosis paru. Dan juga didapatkan nilai $\mathrm{OR}=3,484(\mathrm{CI}=1,246-$ 9, 747) yang berarti status gizi kurang beresiko menderita Tuberkulosis paru sebesar 3,4 kali dibandingkan dengan status gizi cukup.

Penelitian yang dilakukan di Pati (Rusnoto, 2008) dengan desain kasus kontrol melaporkan bahwa seseorang dengan IMT kurang dari 18,5 memiliki resiko 3,79 kali lebih tinggi terserang TB dibandingkan dengan mereka yang memiliki IMT $\geq 18,5$. Penelitian yang dilakukan di Cilacap (Fatimah, 2008) dengan desain yang sama melaporkan bahwa status gizi kurang memiliki risiko 2,74 kali lebih tinggi terserang Tuberkulosis paru dibandingkandengan mereka yang memiliki status gizi baik.

Hasil penelitian ini sesuai dengan penelitian Fariz Muaz (2014) yang menyatakan bahwa terdapat hubungan antara status gizi dengan kejadian Tuberkulosis paru. Karena secara umum kekurangan gizi akan menyebabkan melemahnya sistem imun (kekebalan tubuh) terhadap serangan penyakit.Hasil penelitian ini sesuai dengan penelitian Supriyo (2013) yang menyatakan bahwa status gizi merupakan faktor risiko kejadian Tuberkulosis paru atau ada hubungan antara status gizi dengan kejadian Tuberkulosis paru.

Keadaan status gizi dan penyakit infeksi merupakan pasangan yang terkait. Infeksi dapat menyebabkan kekurangan gizi ataupun sebaliknya kurang gizi juga dapat menghambat dan memperburuk dalam mengatasi penyakit infeksi karena kekurangan gizi dapat menghambat reaksi pembentukan kekebalan tubuh.Schrimshaw et, al mengungkapkan bahwa terdapat hubungan yang erat antara infeksi dengan kurang gizi. Masalah kurang gizi juga masih banyak ditemukan pada negara berkembang seperti Indonesia.

\section{Simpulan}

Berdasarkan hasil penelitian yang dilakukan menunjukkan bahwa terdapat hubungan antara pendapatan dengan kejadian Tuberkulosis paru di wilayah kerja Puskesmas Sempor 1, Kabupaten 
Kebumen $(\mathrm{p}=0,005)$. Dan juga didapatkan nilai $\mathrm{OR}=4,421 \quad(\mathrm{CI}=1,638-11,930)$ yang berarti pendapatan rendah berisiko menderita Tuberkulosis paru sebesar 4,4 kali dibandingkan dengan pendapatan tinggi.

Berdasarkan hasil penelitian yang dilakukan menunjukkan bahwa terdapat hubungan antara status gizi dengan kejadian Tuberkulosis paru di wilayah kerja Puskesmas Sempor 1, Kabupaten Kebumen $(p=0,028)$ dan juga didapatkan nilai $\mathrm{OR}=3,484(\mathrm{CI}=1,246-9,747)$ yang berarti status gizi kurang berisiko menderita Tuberkulosis paru sebesar 3,4 kali dibandingkan dengan status gizi cukup.

\section{DaftarPustaka}

Agus. (2017). Gaji UMR Jateng 2017, Daftar Gaji UMK 35 Kota dan Kabupaten di Jawa Tengah Tahun 2017. http://www.gajiumr.com. Accessed 23 Februari 2017.

Ahmad, Fariza. (2013). Hubungan Status Gizi dengan Tingkat Sosial Ekonomi Orang Tua / Wali Murid Siswa Kelas Atas Sekolah Dasar Negeri 3 Jatiluhur Kecamatan Karanganyar Kabupaten Kebumen. Skripsi. Yogyakarta: UNY.

Amalia, Dewi Rosaria. (2014). Hubungan Pengetahuan dan Motivasi dengan Perilaku Merokok pada Remaja Usia 12 - 15 Tahun di Desa Ngumpul. Tesis. Surakarta: UNS.

Angelina, Bhestsy \&Miskiyah Tiflani Iskandar. (2011). Gizi dan Dietetika (Edisi 2). Jakarta: Penerbit Buku Kedokteran EGC.

Astuti, Sumiyati. (2013). Hubungan Tingkat Pengetahuan dan Sikap Masyarakat terhadap Upaya Pencegahan Penyakit Tuberkulosis di RW 04 Kelurahan Lagoa Jakarta Utara Tahun 2013. Skripsi. Jakarta: UIN.
Budijanto, Didik, dkk (Ed). (2016). 2015 Profil Kesehatan Indonesia. Jakarta: Kemenkes RI

Cahyono, Rinto. (2015). Hubungan Tingkat Ekonomi dengan Kejadian Kekerasan dalam Rumah Tangga di Desa Tersobo Kecamatan Prembun Kabupaten Kebumen. Skripsi. Gombong. Stikes Muhammadiyah Gombong.

Devi, Nirmala. (2010). Nutrition and Food Gizi untuk Keluarga. Jakarta: PT Kompas Media Nusantara.

Dharma, Kelana Kusuma. (2011). Metodologi Penelitian Keperawatan. Jakarta: CV. Trans Info Media.

Haryanto, Sindung. (2011). Sosiologi Ekonomi. Yogyakarta: AR_RUZ MEDIA.

Helper, Sahat P.M. (2010). Faktor-Faktor yang Mempengaruhi Kejadian TB Paru dan Upaya Penanggulangannya. Jurnal Ekologi Kesehatan.

Hidayat, A. Aziz Aimul. (2007). Metode Penelitian Keperawatan dan Teknik Analisis Data. Jakarta: Salemba Medika.

Indarwati, Rini Dwi. (2014). Hubungan Antara Kondisi Sosial Ekonomi dan Perilaku Hidup Sehat dengan Status Gizi Pasien Tuberkulosis Paru di Balai Besar Kesehatan Paru Masyarakat Surakarta. Skripsi. Surakarta: Universitas Muhammadiyah Surakarta.

Kartikasari, BW., Mifbakhuddin, Mustika, DN. (2011). Hubungan Pendidikan, Paritas dan Pekerjaan Ibu dengan Status Gizi Ibu Hamil Trisemester III di Puskesmas Bangetayu Kecamatan Genuk Kota Semarang Tahun 2011. 
Semarang: Universitas Muhammadiyah Semarang.

Kotouki, Anance. (2012). Gambaran Perilaku Penderita dan Resiko Tuberkulosis BTA Positif dengan Kepatuhan Minum Obat dan Kebiasaan Membuang Dahak di Wilayah Puskesmas Ciomas Kabupaten Bogor Propinsi Jawa Barat Tahun 2012. Skripsi. Depok: Universitas Indonesia.

Maksalmina, Z. (2013). Faktor-Faktor yang Menyebabkan Kejadian TB (Tuberkulosis) Paru Pada Laki-Laki di Wilayah Kerja Puskesmas Kedungwuni I Kabupaten Pekalongan. Jurnal Skripsi. Pekalongan: Stikes Muhammadiyah Pekajangan, Pekalongan.

Muaz, Faris. (2014). Faktor-Faktor yang Mempengaruhi Kejadian Tuberkulosis Paru Basil Tahan Asam Positif Di Puskesmas Wilayah Kecamatan Serang Kota Serang Tahun 2014. Skripsi. Jakarta: UIN.

Noor, Nur Narsy. (2008). Epidemiologi. Jakarta: Rineka Cipta.

Notoatmodjo, Soekidjo. (2012). Metode Penelitian Kesehatan. Jakarta: PT RINEKA CIPTA

P, Ristyo Sari, dkk. (2012). Hubungan Tingkat Sosial Ekonomi dengan Angka Kejadian Tuberkulosis Paru BTA Positif di Wilayah Kerja Puskesmas Peterongan Jombang Tahun 2012. Skripsi. Jombang: Stikes PEMKAB Jombang.

Patiung, F., Wongkar, MCP dan Mandang, V. (2014). Hubungan Status Gizi dengan CD4 Pasien Tuberkulosis Paru. Jurnal e-CliniC, volume 2, nomor 2.
Purwitasari, Sri, dkk. (2016). Profil Kesehatan Kabupaten Kebumen 2015. Kebumen: Dinas Kesehatan Kabupaten Kebumen

Putra, Niko Rianda. (2011). Hubungan Perilaku dan Kondisi Sanitasi Rumah dengan Kejadian TB Paru Di Kota Solok Tahun 2011. Skripsi. Padang: Universitas Andalas Padang.

Priyatiningsih, Sri Endah. (2012). Hubungan Antara Status Gizi dengan Tingkat Konsentrasi Belajar Siswa Kelas III dan IV di SDN 1 Pekutan Kecamatan Mirit. Skripsi. Gombong: Stikes Muhammadiyah Gombong.

Rohman, WK. (2012). Faktor-Faktor yang berhubungan dengan Kejadian TB Paru di Wilayah Kerja Puskesmas Gabus II Kabupaten Grobogan. Jurnal Skripsi. Semarang: Universitas Muhammadiyah Semarang.

Romlah, Laila. (2015). Hubungan Merokok Dengan Kejadian Penyakit Tuberkulosis Paru Di Wilayah Kerja Puskesmas Setu Kota Tangerang Selatan. Skripsi.Jakarta: UIN.

Rusnoto. (2008). Faktor-Faktor yang Berhubungan dengan Kejadian TB Paru pada Usia Dewasa (Studi Kasus di Balai Pencegahan dan Pengobatan Penyakit Paru Pati). Jurnal Epidemiologi. Semarang: Universitas Diponegoro.

Ruswanto, Bambang. (2010). Analisis Spasial Sebaran Kasus Tuberkulosis Paru Ditinjau dari Faktor Lingkungan Dalam dan Luar Rumah di Kabupaten Pekalongan. Tesis. Semarang: Universitas Diponegoro.

Sianturi, Ruslantri. (2013). Analisis Faktor yang Berhubungan dengan 
Kekambuhan TB Paru. Skripsi. Semarang: UNNES.

Subarjo, Pana Agus. (2014). Faktor-Faktor yang Mempengaruhi Kinerja Kader dalam Penemuan Suspek Tuberkulosis Paru di Puskesmas Sruweng Kabupaten Kebumen. Skripsi. Gombong: Stikes Muhammadiyah Gombong.

Sudiantara, Ketut., dkk. (2014). FaktorFaktor yang Mempengaruhi Peningkatan Kasus TB Paru. Denpasar: Poltekes Denpasar

Sugiyono. (2016). Metodologi Penelitian Kombinasi (mixed methods). Bandung: ALFABETA

Supriyo, dkk. (2013). Pengaruh Perilaku dan Status Gizi terhadap Kejadian TB Paru di Kota Pekalongan. Semarang: Poltekes Semarang.

Syarfa, Ilyati. (2015). Gambaran Tingkat Pengetahuan, Perilaku Merokok dan Nikotin Dependen Mahasiswa UIN Syarif Hidayatullah Jakarta. Skripsi. Jakarta: UI 